\title{
ANALISIS SISTEM INFORMASI MANAJEMEN DALAM MENINGKATKAN KUALITAS PELAYANAN DI UNIVERSITAS ISLAM NEGERI SUMATERA UTARA
}

Risti rambe

\section{Prodi Sistem Informasi, Fakultas Sains Dan Teknologi, Uin Sumatera Utara}

ristirohil@gmail.com

\begin{abstract}
This article discusses the analysis of management information systems in improving service quality at the State Islamic University of North Sumatra. From the research, it can be seen that the management information system that runs at the Islamic State University of North Sumatra has been running well, but information processing humans still have shortages and equipment support, such as the lack of fast internet network, many system services that do not function properly, and also minimal resources. With the management information system can be increased from a manual to an online-based system. The management information system in improving the quality of service at the State Islamic University of North Sumatra has been going well compared to using the manual method which takes a long time, by using a management information system, empathy and responses can increase and can provide quality information faster, easier. and not complicated. With the management information system at the Faculty of Science and Technology at the State Islamic University of Sumatra, it is hoped that academic information managers can improve the quality of their services to users.
\end{abstract}

Keywords: management information system, service quality 


\begin{abstract}
Abstrak
Artikel ini membahas tentang sistem informasi manajemen dalam meningkatkan kualitas pelayanan di Fakultas Sains dan Teknologi UIN Sumatera Utara. Dari eksplorasi tersebut sangat terlihat bahwa sistem informasi manajemen yang berjalan di Fakultas Sains dan Teknologi UIN Sumatera Utara sudah berjalan dengan baik, namun orang-orang yang menangani data sebenarnya memiliki kekurangan dan dukungan peralatan, misalnya tidak adanya organisasi web yang cepat. , banyak manfaat kerangka kerja yang tidak berfungsi seperti yang diharapkan, dan juga aset yang tidak signifikan. Dengan kerangka data administrasi dapat diperluas dari manual ke kerangka berbasis online.
\end{abstract}

Sistem Informasi Manajemen dalam meningkatkan kualitas pelayanan di Fakultas Sains dan Teknologi Universitas Islam Negeri (UIN) Sumatera Utara sudah berjalan secara umum dibandingkan dengan menggunakan cara manual yang memakan waktu cukup lama, dengan memanfaatkan kerangka data administrasi, kasih sayang dan reaksi dapat bertambah dan dapat memberikan data berkualitas lebih cepat, lebih sederhana. apa lagi, tidak kacau. Dengan adanya Sistem Informasi Manajemen pada kualitas pelayanan di Fakultas Sains dan Teknologi Universitas Islam Negeri (UIN) Sumatera Utara, dipercaya para pengelola data skolastik dapat meningkatkan sifat administrasinya kepada klien.

Kata kunci: Sistem Informasi Manajemen, Kualitas Pelayanan 


\section{PENDAHULUAN}

Pada dasarnya, sistem informasi manajemen adalah bagian yang terdiri dari individu, inovasi data, dan metodologi kerja yang berinteraksi, menyimpan, membedah, dan menyebarkan data untuk mencapai suatu tujuan. Kerangka kerja data administrasi berbasis inovasi data adalah kerangka kerja pembuatan data yang menjunjung tinggi pengumpulan administrator dengan menggunakan inovasi data (McLeod, Jr. 2001:49). Pemanfaatan inovasi data ini pada akhirnya akan mempengaruhi eksekusi otoritatif. Saat ini di perhimpunan/organisasi swasta namun juga di kantor-kantor pemerintahan. Inovasi data yang bergantung pada inovasi data ini akan mempengaruhi aktivitas pekerja, sehingga memudahkan perwakilan untuk saat ini tidak melakukan pekerjaan fisik sehingga pekerjaan dapat diselesaikan dengan baik dan benar.

Untuk membuat data yang solid, diperlukan suatu sistem informasi manajemen (SIM) yang dapat memenuhi dan menangani informasi serta menghasilkan data yang tepat dan akurat kapanpun. Tanpa dukungan SIM yang solid maka sulit untuk diakui amalan-amalan keilmuan yang dapat diterima, karena SIM membantu latihan-latihan dalam bidang apapun dalam mengkoordinasikan informasi dan mempercepat informasi di Fakultas Sains dan Teknologi UIN Sumatera Utara, dipercaya pameran tersebut. administrasi regulasi, khususnya skolastik, akan meningkat. Melihat pentingnya SIM dalam meningkatkan kualitas pelayanan, untuk membantu kegiatan akademik berbasis online, maka penulis menyusun artikel ini dengan topik "Analisis Sistem Informasi Manajemen dalam Meningkatkan Kualitas Pelayanan di Fakultas Sains dan Teknologi UIN Sumatera Utara”. 


\section{STUDI LITERATURE}

Studi literature yang bersumber dari buku-buku, jurnal, karya-karya ilmiah, dan sebagainya yang berbicara tentang sitem informasi manajemen dengan konsep "Analisis Sistem Informasi Manajemen dalam Meningkatkan Kualitas Pelayanan ".

\section{METODE PENELITIAN}

Metode yang diterapkan adalah metode pengamatan atau observasi dan pengumpulan serperti:

- Mengamati setiap objek yang berhubungan dengan topik yang diteliti, seperti menggunakannya langsung dalam mengakses website akademik yang diteliti, hingga didapat sebuah hasil atau bukti nyata.

- Searching atau keperpustakaan dengan mengumpulkan beberapa informasi dari buku-buku yang dibaca yang berhubungan dengan topic yang diteliti.

- Mengumpulkan hasil bukti nyata yang didapat dari pengamatan dari sumber yang berhubungan dengan topic yang diteliti.

\section{PEMBAHASAN}

\section{Sistem informasi manajemen berjalan di Fakultas Sains dan Teknologi UIN Sumatera Utara}

Sistem informasi manajemen dalam Peningkatan Kualitas pelayanan di Fakultas Sains dan Teknologi UIN Sumatera Utara menunjukkan hasil yang beragam. Dari hasil eksplorasi termasuk sumber-sumber yang telah menanggapi 
beberapa pertanyaan pemeriksaan yang diajukan oleh para ahli dari faktorfaktor kerangka data eksekutif dan kualitas administrasi di mana para ilmuwan menggunakan faktor kerangka data dewan menggunakan teori Gordon B. Davis, (2009: 57) yang mengungkapkan bahwa ada 5 ( lima) penanda system informasi manajemen diantaranya, manusia sebagai pengolah informasi, konsep sistem, konsep pengambilan keputusan dan nilai informasi. Sedangkan sifat analis administrasi menggunakan teori Parasuraman dan Zeithaml, (2009: 180) yang meningkatkan sepuluh petunjuk menjadi lima penanda prinsip yang dikenal dengan Serqual (Service Quality) yang terdiri dari bukti fisik, keandalan, daya tanggap, jaminan dan empati.

\section{a). Informasi}

Berjalannya informasi melalui sistem informasi manajemen berbasis online di Fakultas Sains dan Teknologi UIN Sumatera Utara tidak berarti tidak ada halangan dan dapat diterima, sistem informasi manajemen secara khusus untuk bidang akademik telah data yang diberikan kepada pengguna, baik itu guru, mahasiswa dan perwakilan atau staf tertentu namun masih belum ideal, perlu ada peningkatan dalam kerangka kerja yang sebenarnya, terutama di SDM-nya selain peralatan dan instrumen untuk membantu kerangka kerja tersebut. Oleh karena itu, sistem pengelolaan data berbasis online di Angkatan Kerja Ilmu Pengetahuan dan Inovasi terkait dengan data telah berjalan dengan baik namun masih belum optimal. Sesuai penilaian Gordon B. Davis, (2009:57) yang menjelaskan bahwa data merupakan akibat dari penyiapan informasi namun tidak semua akibat dari penanganan dapat berupa data, akibat dari penanganan informasi yang tidak memberikan arti dan tidak membantu untuk seseorang bukan data untuk orang lain. bahwa. 


\section{b). Manusia Sebagai Pengolah Informasi}

Hasil penelitian menunjukkan bahwa sistem informai manajemen berjalan di di Fakultas Sains dan Teknologi UIN Sumatera Utara, salah satunya adalah hadirnya SDM sebagai pengolah informasi untuk di Fakultas Sains dan Teknologi UIN Sumatera Utara. Personil Iptek, di Fakultas Sains dan Teknologi UIN Sumatera Utara, memanfaatkan data yang disampaikan atau diberikan oleh system informasi manajemen, dimana informasi data dewan diurus oleh pekerja yang sudah terbiasa memanfaatkan dan mahir inovasi, sehingga data yang disampaikan sangat vital dan dibutuhkan oleh pengguna. Aset sebagai pengolah data tentunya harus diisi oleh individu-individu yang terdidik inovasi seperti apa yang diturunkan oleh Fakultas Sains dan Teknologi UIN Sumatera Utara, namun dengan banyaknya jumlah pengguna atau pengguna informasi ini, tentunya membutuhkan jumlah yang sangat banyak. fakultas atau pekerja untuk saat ini menangani data di Fakultas Sains dan Teknologi UIN Sumatera Utara sudah cukup, namun harus ditambah dengan peningkatan inovasi sekarang. Untuk di Fakultas Sains dan Teknologi UIN Sumatera Utara sendiri sudah mencukupi namun untuk peangkat kantor harus ditambah.

\section{c). Konsep Sistem}

Disadari bahwa gagasan yang digunakan adalah gagasan yang telah dibuat melalui jadwal ilmiah serta penyusunan, definisi yang rumit untuk mencapai tujuan akhir tertentu adalah tindakan administrasi yang disebut penataan. Dengan cara ini, pengaturan memerlukan penetapan tujuan dan pengenalan teknik untuk mencapai tujuan ini. Di mana ide penyusunan kerangka kerja ini bisa berupa PC fokus atau bisa juga merupakan kumpulan dari beberapa PC kecil. Pemikiran prinsipnya adalah campuran yang tersusun dari aplikasi yang dapat dilakukan dan menarik. Dari hasil penelitian, analis dapat menemukan bahwa setiap kerangka data administrasi tertentu di bidang skolastik akhirnya memiliki manfaat dan ketidaknyamanan dan digabungkan 
dengan ide-ide yang telah disusun tergantung pada jadwal ilmiah yang ditegakkan dengan pengaturan, kontrol dan dinamis yang dibedah. memanfaatkan swot untuk menemukan kelebihan dan kekurangannya. . Padahal manfaat dari sistem informasi manajemen luar biasa online dalam bidang keilmuan pada Kepegawaian Teori Sosial Politik adalah: Kantor Krs Online ini dapat dimanfaatkan oleh mahasiswa Fakultas Sains dan Teknologi UIN Sumatera Utara, 24 jam, Non antrian dan beban ringan.

Terkait konsep sistem yang digunakan atau ditawarkan oleh Fakultas Sains dan Teknologi UIN Sumatera Utara untuk menjalankan sistem informasi manajemen, penting untuk membuat sistem informasi manajemen dengan alasan bahwa aset yang dimiliki oleh Fakultas Sains dan Teknologi UIN Sumatera Utara sangat dibatasi, sehingga harus dimanfaatkan secara ideal. Ide ini juga digunakan untuk meningkatkan kualitas administrasi karena pesaing memiliki aset inovasi yang sama dan menjamin bahwa sumber daya inovasi data dapat digunakan dengan baik.

Secara langsung atau tidak langsung dalam meningkatkan sifat administrasi pada Staf Fakultas Sains dan Teknologi UIN Sumatera Utara, baik kepada pengajar, mahasiswa maupun pekerja itu sendiri. Demikian pula, gagasan kerangka kerja berbasis data administrasi ilmiah online digunakan untuk menemukan manfaat atau kelemahan dan menjamin bahwa inovasi data yang disusun benar-benar menjawab kebutuhan pengajar, siswa, perwakilan untuk data yang dibutuhkan. Ide kerangka seperti yang ditunjukkan oleh Gordon B. Davis, (2009:114) dapat digambarkan sebagai berikut:

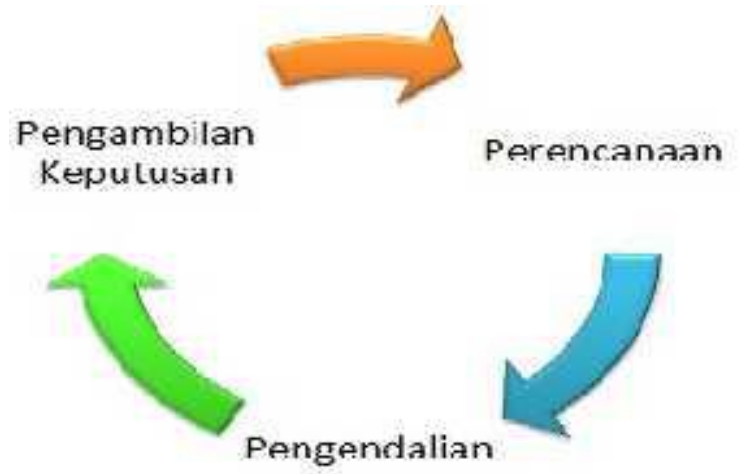


Konsep Sistem, Gordon B. Davis, 2009:114

Selain sistem informasi manajemen yang berbasis online dalam meningkatkan kualitas pelayan, ia menikmati manfaat dan kerugian seperti ideide yang diterapkan dan dijalankan sehingga diketahui perbedaan antara sistem manual dan elektronik/online, jelas, membutuhkan Staf Fakultas Sains dan Teknologi UIN Sumatera Utara untuk melakukan perawatan. Berdasarkan hasil wawancara dari beberapa informan, ditemukan bahwa pemeliharaan dalam sistem seperti pemeriksaan sesekali, ulasan dan permintaan pengguna akan menjadi source untuk melakukan pemeliharaan sistem selama keberadaan sistem. Pemeliharaan sistem adalah pendekatan paling ideal untuk menjaga keefisien sistem saat ini. Seperti kata pepatah, lebih baik memelihara daripada mengganti.

\section{d). Konsep Pengambilan Keputusan}

Mengingat konsekuensi dari pemeriksaan dan dikuatkan oleh penilaian Gordon B. Davis, (2009: 96) yang menyatakan bahwa gagasan dinamis adalah perkembangan langkah-langkah berpikir kritis yang menjamin bahwa masalah pertama kali dirasakan, pengaturan elektif adalah dipikirkan, dan pengaturan yang dipilih berhasil. Cara-caranya adalah sebagai berikut: Upaya untuk bersiap-siap, Upaya untuk mengkarakterisasi/membedakan masalah yang akan ditangani, Pengaturan solusi.

Pimpinan Fakultas Sains dan Teknologi UIN Sumatera Utara terlibat dengan pemikiran kritis untuk dinamis yang efisien dan efektif. Pentingnya berpikir kritis tidak tergantung pada ukuran waktu yang dihabiskan untuk hasil. Dinamis adalah demonstrasi memilih ide/kegiatan yang diterima oleh perintis akan memberikan jawaban terbaik untuk masalah tersebut. Salah satu kunci untuk berpikir kritis adalah mengenali pilihan yang berbeda dari pilihan lain. Derajat 
penyempurnaan diselesaikan di area utama, jika terjadi masalah di Staf, pengelola tenaga kerja harus melaporkannya ke Fakultas sehingga Pengurus Fakultas akan turun ke bagian personalia dan sebaliknya jika ada masalah di tingkat Fakultas, pengelola Fakultas akan turun ke pegawai untuk memberitahukan atau " by phone”. Kemudian, pada saat itu secara dinamis mengikutsertakan semua pengelola kepegawaian untuk membagi antar sumber daya, namun sebelum itu diadakan rapat terlebih dahulu untuk mendapatkan informasi, kemudian, pada saat itu dinamika diselesaikan dalam sebuah rapat pimpinan yang dipimpin oleh Rektor selaku bidang akademik bersama seluruh komponen administrasi tenaga kerja untuk mengatasi permasalahan yang sedang terjadi atau ada, khususnya hal-hal penting yang berkaitan dengan akademik.

\section{e). Nilai Informasi}

Hasil yang didapat oleh analis bahwa sistem informasi manajemen adalah sistem berbasis komputer online yang memberikan data kepada beberapa pengguna atau pengguna dengan persyaratan yang sebanding. Menghasilkan informai oleh pionir atau bos seperti pekerja di asosiasi untuk menentukan pilihan dalam menangani masalah. Jadi seperti yang ditunjukkan oleh kepala biro akademik pada umumnya, nilai data merupakan penyesuaian perilaku pilihan yang ditimbulkan oleh informasi, pada akhirnya cenderung dihadapkan pada beberapa pilihan potensial. Misalnya, seorang kepala suku akan memilih satu mengingat data yang dimilikinya, menyiratkan bahwa nilai data sangat membantu bergantung pada cara kita menilainya. Nilai suatu data diidentifikasi dengan pilihan. Ini menyiratkan bahwa ketika tidak ada keputusan atau pilihan, data tidak ada gunanya. Pilihan dapat berubah dari pilihan sederhana yang membosankan hingga pilihan strategi jangka panjang.

Fakultas Sains dan Teknologi UIN Sumatera Utara harus memahami bahwa mereka cukup praktis dalam keinginan mereka, berhati-hati dalam merencanakan dan melaksanakan kerangka data eksekutif dalam meningkatkan 
kualitas bantuan sehingga mereka seperti yang diinginkan dan masuk akal dalam menawarkan jenis pelayanan kepada pengguna seperti instruktur, mahasiswa dan staf Fakultas Sains dan Teknologi UIN Sumatera Utara dan kelebihan yang akan diperoleh. Dari hasil wawancara pimpinan Fakultas Sains dan Teknologi UIN Sumatera Utara, disadari bahwa ada banyak sekali nilai penting dalam data yang kami dapatkan, salah satunya tentang skolastik seperti Siakad, feeder fundamental. diidentikkan dengan skolastik. Misalnya, sejauh nilai data yang bisa diambil misalnya, kita bisa mengetahui di mana mahasiswa dalam mendalangi KRS, mengetahui aksi mereka saat berpidato dan yang tak kalah penting, kita bisa melihat kualitas keilmuannya, selain itu kita juga bisa melihat. melihat dan mengawasi pekerja yang menawarkan bantuan pendidikan kepada pengguna, bagaimana dia melayani dan memberikan informasi, menjawab pertanyaan, dan bahkan menangani masalah yang muncul. Jadi di sana kita bisa mengevaluasi data.

Berkaitan dengan nilai informasi dari suatu sistem informasi manajemen, khususnya bidang-bidang yang diidentikkan dengan akademik, jika dilihat dari tingkat pendidikannya, cukup memadai, dan jika berdasarkan jumlah pegawai Fakultas Sains dan Teknologi UIN Sumatera Utara, sudah cukup jika melihat konstruksi saat ini, namun penting untuk menambah SDM yang identik dengan skolastik karena tidak semata-mata dapat menawarkan jenis bantuan, mereka juga dapat meningkatkan manfaat sehingga data sebagai informasi kemudian ditambahkan. Disiapkan dengan tujuan agar menjadi data yang penting, meskipun saat ini data yang diperoleh sangat dapat diterima, namun tidak ada salahnya menambah perwakilan karena banyak yang ditangani, seperti laporan dan lain-lain. Mengingat data dari sumber, penting untuk menambah pekerja tambahan, terutama yang diidentifikasi dengan skolastik untuk meningkatkan sifat administrasi dalam memberikan data yang berharga kepada pengguna. Perluasan perwakilan, khususnya di bidang Fakultas Sains dan Teknologi UIN Sumatera Utara berharap dapat meningkatkan keterbukaan informasi yang diperkenalkan secara tepat dan tepat 
kepada pengguna, tanpa memerlukan mediator sistem informasi, menjamin aksesibilitas nilai dan kemampuan dalam menggunakan kerangka data secara mendasar, menciptakan ukuran

pengaturan yang kuat, mengenali kebutuhan akan kemampuan pelayanan sistem informasi manajmen memutuskan usaha untuk dikoordinasikan dalam sistem informasi, mengharapkan dan memahami hasil keuangan kerangka data dan inovasi baru dan meningkatkan efisiensi dalam pengembangan kerangka kerja dan aplikasi pemeliharaan. Sehingga nilai data dapat bermanfaat dan signifikan menurut pengguna.

\section{Kualitas Pelayanan Di Fakultas Sains Dan Teknologi UIN Sumatera Utara Dengan Adanya Sistem Informasi Manajemen Berbasis Sistem Informasi Akademik Dengan Sistem Online}

Kualitas layanan terkait sistem informasi manajemen dapat dilihat dari pendekatan yang dilakukan salah satunya adalah konsep dimensi kualitas layanan dari Parasuraman Zeithaml. Dengan demikian kualitas pelayanan yang akan dikaji dalam penelitian ini adalah kualitas pelayanan sistem informasi manajemen yang diberikan oleh pegawai pada Fakultas Sains dan Teknologi UIN Sumatera Utara mengenai bukti langsung ketanggapan, jaminan, keandalan dan empati.

\section{a). Bukti Fisik (Tangibles)}

Dari hasil pemeriksaan tersebut, disadari bahwa kemampuan staf Fakultas Sains dan Teknologi UIN Sumatera Utara dalam menunjukkan realitasnya kepada guru, mahasiswa dan perwakilan di lingkungan Fakultas Sains dan Teknologi UIN Sumatera Utara sebanding dengan akademik sangat dapat diterima. . Penampilan dan kapasitas kantor dan sistem Fakultas Sains dan Teknologi UIN Sumatera Utara yang solid serta keadaan iklim secara umum merupakan salah satu cara dimana Fakultas Sains dan Teknologi UIN Sumatera Utara menyajikan sistem informasi manajmen dalam meningkatkan 
kualitas pelayanan. Ini termasuk kantor aktual (struktur, buku, rak, meja dan kursi, dan sebagainya), inovasi (perangkat keras dan peralatan yang digunakan), dan penampilan pekerja. Hasil penyelidikan mengungkapkan bahwa bukti nyata yang diberikan oleh pekerja penyiapan data di Fakultas Sains dan Teknologi UIN Sumatera Utara sangat dapat diterima, dan diidentifikasi dengan peralatan dan perangkat pendukung untuk kerangka data administrasi ilmiah yang unik masih ada masalah sejak itu. itu diidentifikasi dengan rencana keuangan, tetapi diidentifikasi dengan bukti nyata seperti struktur., meja dan kursi tidak ikut campur masih dalam kondisi yang layak namun tetap bisa dimanfaatkan walaupun harus dirawat dan ditambah, apalagi jaringan internet yang tentunya membutuhkan dana besar masih menjadi kendala namun umumnya semuanya bisa. berjalan dengan baik, khususnya pada Fakultas Sains dan Teknologi UIN Sumatera Utara.

Menurut Parasuraman, A. Zaithami, dalam Ariani (2010: 9) bahwa kualitas bantuan adalah kemampuan untuk menawarkan jenis bantuan yang berkualitas kepada pengguna baik melalui layanan khusus atau layanan administratif. Sistem unformsi manajemen akademik adalah susunan yang paling banyak digunakan dalam mengawasi informasi akademik organisasi pendidikan di Indonesia. Selain meningkatkan informasi interaksi eksekutif, sistem informasi ini juga mengurangi biaya operasional yang harus dikeluarkan oleh organisasi terkait. Dengan cara ini, pegawai Fakultas Sains dan Teknologi UIN Sumatera Utara mencoba meningkatkan sifat pelayanannya melalui aset yang dapat diandalkan dalam mengawasi data dengan tujuan agar dapat dimanfaatkan oleh pengguna dengan cepat dan baik. Sesuai dengan apa yang disampaikan oleh otoritas Staf Fakultas Sains dan Teknologi UIN Sumatera Utara, bahwa sistem informasi manajemen online, khususnya akademik, pasti dapat meningkatkan sifat pelayanan secara lugas, yang dapat kita input sendiri, informasi itu bernilai penting atau tidak. 


\section{b). Keandalan (reliability)}

Dari hasil pemeriksaan, para ilmuwan memperoleh data bahwa prinsip dalam menawarkan jenis bantuan, pejabat tidak boleh ragu-ragu, tanpa penyimpangan ketika berhubungan dengan teknik, dan memenuhi keinginan instruktur, siswa. Keandalan ini terlihat dari data para saksi yang diperjelas dan diperkuat oleh penilaian Ratminto, (2005:47) yang menyatakan bahwa pelaksanaan Implementasi Reliability (Keandalan) pada kualitas pelayanan dalam memberikan informasi menggunakan sistem informasi manajemen akademik , secara spesifik: a. Kemampuan Fakultas Sains dan Teknologi UIN Sumatera Utara Dalam Memecahkan Masalah Dengan Baik, b. Ketepatan Waktu Pelayanan, c. Ketertiban Administrasi, d.Kedisiplinan Pegawai Pelayanan.

\section{c). Daya Tanggap (responsiveness) Ketanggapan Pegawai Pelayanan}

Pertimbangan Fakultas Sains dan Teknologi UIN Sumatera Utara terhadap perwakilan, khususnya pengolah info akademik untuk membangun daya tanggap dalam menawarkan jenis pelayanan kepada pembicara dan siswa adalah memberikan arahan kepada perwakilan melalui korespondensi biasa, dan melalui pertemuan institusional biasa. Selain itu, Fakultas Sains dan Teknologi UIN Sumatera Utara juga membuka peluang bagi perwakilan kemasyhuran besar yang akan ditentukan untuk melanjutkan ke sekolah yang lebih tinggi untuk memperkuat panggilan bisnis mereka dan lebih dominan dan responsif dalam menawarkan jenis bantuan kepada dosen dan mahasiswa.

\section{Kemampuan dalam memberikan informasi (ketepatan informasi yang diberikan)}

Sebagai pelaksanaan administrasi akademik dalam meningkatkan sifat administrasi, Staf Fakultas Sains dan Teknologi UIN Sumatera Utara, melakukan strategi untuk masalah berikut: dari jenis keseluruhan, termasuk; Sosialisasi SOP (Standard Working System), sosialisasi administrasi regulasi 
hingga pelaksanaan masa presentasi kehidupan dasar bagi mahasiswa baru, Penetapan bendera yang ditandai dengan perkembangan administrasi regulasi, Penetapan rencana hari kerja bagi staf otoritatif dan kepala data ilmiah dan Sosialisasi administrasi manajerial melalui penetapan pengumuman/baner.

\section{Kesediaan untuk Membantu dalam Pelayanan}

Sebagian besar pekerja penanganan data atau informasi pada Staf Fakultas Sains dan Teknologi UIN Sumatera Utara, mengabdikan kapasitasnya sepenuhnya untuk mengabdi. Dengan cara ini, untuk menjaga kekuatan administrasi yang diberikan oleh penyiapan data perwakilan Staf Fakultas Sains dan Teknologi UIN Sumatera Utara, kepada para guru, mahasiswa, Fakultas Sains dan Teknologi UIN Sumatera Utara,serta pemberian seleri sebagai Pengganti gaji (walaupun yang nyata tidak hanya sebesar gaji), juga memberikan keuntungan lain sesuai dengan kemampuan Fakultas Sains dan Teknologi UIN Sumatera Utara. Hasil pemeriksaan didapatkan data bahwa administrasi yang diberikan oleh Fakultas Sains dan Teknologi UIN Sumatera Utara, diidentikkan dengan kerangka data administrasi berbasis online, khususnya di bidang skolastik yang diizinkan oleh petugas penanganan data, antara lain:

1. Membulatkan kartu rencana investigasi ke siswa

2. Kerangka Data Layak untuk instruktur dan siswa

3. Ketidakhadiran Kelas Mahasiswa, Rundown Partisipasi Instruktur

4. EPSBED

5. Administrasi Pergerakan Mahasiswa

6. Administrasi Ujian dan Administrasi Pembicara

7. Perpustakaan, layanan administrasi buku harian

8. Latihan Mendidik Dosen 


\section{PENUTUP}

\section{1. kesimpulan}

Mengingat efek samping dari pemeriksaan dan percakapan tentang Investigasi sistem informasi manajemen dalam meningkatkan kualitas pelayanan di fakultas sains dan teknologi uin sumatera utara para analis dapat memberikan tujuan sebagai berikut:

a) bahwa sistem informasi manajemen yang berjalan di Fakultas Sains Dan Teknologi Uin Sumatera Utara sudah berjalan dengan baik dari lima petunjuk yang tercatat. Para ilmuwan menggunakan, bagaimanapun, dari orang-orang sebagai pengolah data masih ada kelemahan dan dukungan perangkat keras yang masih kecil, misalnya, tidak adanya kecepatan jaringan web, banyak administrasi dalam kerangka kerja yang tidak berfungsi dan aset yang tidak signifikan.

b) Bahwa Hakikat manajemen pada Fakultas Sains Dan Teknologi Uin Sumatera Utara dengan adanya sistem informasi manajemen dapat meningkat dari sebelumnya sistem manual kemudian, kemudian berubah menjadi kerangka kerja berbasis online, dari lima penanda yang digunakan spesialis secara khusus dalam kualitas fisik dan tidak tergoyahkan yang sebenarnya harus ditingkatkan, seperti jumlah meja, kursi, dan perlengkapan yang telah ditentukan sesuai dengan rencana pengeluaran. dan SDM yang dibatasi.

\section{Saran}

Mengingat pemeriksaan dan percakapan dan akhir, para spesialis dapat memberikan konsekuensi yang menyertainya:

a) Mengingat efek samping dari penyelidikan, ditemukan bahwa orang-orang sebagai pengolah data sebenarnya membutuhkan perangkat keras dan 
dukungan. Akibatnya, inisiatif dari Staf Fakultas Sains Dan Teknologi Uin Sumatera Utara harus memiliki opsi untuk meningkatkan SDM yang ada agar dapat diterapkan pada kebutuhan Fakultas Sains Dan Teknologi Uin Sumatera Utara, dan memiliki opsi untuk memberikan dukungan peralatan sebagai perangkat keras untuk kerangka data administrasi itu sendiri, misalnya dengan menambahkan peralatan perwakilan di bidang keilmuan dengan melihat landasan edukatif. yang dapat menyimpan data sekolah berbasis online dan menyediakan perangkat keras yang sesuai dengan kemajuan mekanis saat ini, misalnya, komputer dengan jaringan wifi berkecepatan tinggi yang didukung oleh berbagai bagian.

b) Berdasarkan hasil pemeriksaan, terbukti bahwa bukti nyata dan kualitas yang tak tergoyahkan masih sangat terbatas, seperti meja, kursi, meskipun SDM dibatasi karena rencana keuangan. Oleh karena itu, kewenangan Staf Fakultas Sains Dan Teknologi Uin Sumatera Utara seharusnya lebih meningkatkan aksesibilitas meja dan kursi dengan bekerja sama dengan otoritas publik dan pertemuan pribadi sejauh perolehan barang dagangan, serta mencari aset dari luar melalui MoU atau penghargaan Sama seperti memilih perwakilan baru untuk menambah aset lancar dengan melihat sesuai pesanan yang dimiliki, diyakini sifat administrasi pada Fakultas Sains Dan Teknologi Uin Sumatera Utara dapat meningkat dari bidang akademik. 


\section{DAFTAR PUSTAKA}

Davis, Gordon B. 2009. Kerangka Dasar Sistem Informasi Manajemen. Jakarta. Pustaka Binaman Presindo

Jusuf Suit, Almasdi. 2012. Aspek Sikap Mental Dalam Manajemen Sumber Daya Manusia, Jakarta.

Galia Indonesia. Kasmir, 2005. Manajemen Pemasaran Di Indonesia. Jakarta. Raja Grafindo Persada

Saleh, Wolkins. 2010. Manajemen Dan Enam Prinsip Pokok Kualitas Pelayanan. Jakarta.Para Pelaksana Dan Enam Standar Utama Kualitas Administrasi. Jakarta

Siagian, Sondang P. 2009. Sistem Informasi Manajemen. Jakarta. Bumi Aksara

Stoner, James A.F. 1996. Pengantar Sistem Informai Manajemen. Jakarta. Intermedia

Jurnal Ilmiah Mahasiswa Universitas Surabaya Vol.2 No.1 (2013) "Analisis Dan Perancangan Sistem Informasi Manajemen Hubungan Terhadap Donator Untuk Meningkatkan Loyalitas Dan Jumlah Donator Vihara Dhammadipa Surabaya"

Jurnal Vol. 3 No. 2 AGUSTUS 2017 "Jurnal Kebijakan \& Pelayanan Publik"

Sugiyono, 2011. Pendekatan Kuantitatif, Kualitatif, dan R\&D Bandung. Alfabeta 
Sutedjo, Budi. 2007. Pembangunan Sistem Informasi. Jakarta: Pt. Grasindo.

Tjiptono, Fandy. 2012. Manajemen Pemasaran Dan Pelayanan Modern. Andi Ofset.

Zahruli, 2006. Mutu dan Kualitas Pelayanan. Jakarta, Pt. Media Cipta 